\title{
Expression of sodium-iodide symporter mRNA in the thyroid gland of Xenopus laevis tadpoles: developmental expression, effects of antithyroidal compounds, and regulation by TSH
}

\author{
Robert Opitz, Achim Trubiroha, Claudia Lorenz, Ilka Lutz, Sabine Hartmann', Tobias Blank, \\ Thomas Braunbeck ${ }^{1}$ and Werner Kloas ${ }^{2}$ \\ Department of Inland Fisheries, Leibniz-Institute of Freshwater Ecology and Inland Fisheries, Mueggelseedamm 310 , D-12587 Berlin, Germany \\ ${ }^{1}$ Aquatic Ecology and Toxicology, Department of Zoology, University of Heidelberg, D-69120 Heidelberg, Germany \\ ${ }^{2}$ Department of Endocrinology, Institute of Biology, Humboldt University, D-10115 Berlin, Germany \\ (Requests for offprints should be addressed to W Kloas; Email: werner.kloas@igb-berlin.de)
}

\begin{abstract}
The uptake of iodide represents the first step in thyroid hormone synthesis by thyroid follicular cells and is mediated by the sodium-iodide symporter (NIS). In mammals, expression of NIS is stimulated by TSH and transcription of the NIS gene involves regulation by the thyroid-specific transcription factors Pax8 and $\mathrm{Nkx} 2 \cdot 1$. In this study, we examined the mRNA expression of NIS, Pax8 and Nkx2 1 in the thyroid gland of Xenopus laevis tadpoles by semiquantitative reverse transcriptase (RT)-PCR. During spontaneous metamorphosis, NIS mRNA expression was low in premetamorphic tadpoles, increased throughout prometamorphosis, and peaked at climax stage 60 . Analysis of TSH $\beta$ subunit (TSH $\beta$ ) mRNA in the pituitary of the same tadpoles revealed a close temporal relationship in the expression of the two genes during metamorphosis, suggesting a regulatory role of TSH in the developmental expression of NIS. Treatment of tadpoles with goitrogenic compounds (sodium perchlorate and ethylenethiourea) increased TSH $\beta$ mRNA expression (approximately twofold) and caused thyroid gland hyperplasia, confirming that feedback along the pituitary-thyroid axis
\end{abstract}

was operative. Analysis of gene expression in the thyroid gland revealed that goitrogen treatment was correlated with increased expression of NIS mRNA ( 20-fold). In the thyroid gland organ culture experiments, bovine TSH (bTSH; $1 \mathrm{mU} / \mathrm{ml}$ ) strongly induced NIS mRNA expression. This effect was mimicked by co-culture of thyroid glands with pituitaries from stage 58 tadpoles and by agents that increase intracellular cAMP (forskolin, dibutyryl-cAMP). In addition, it could be shown that thyroid glands of $X$. laevis tadpoles express Pax8 and $\mathrm{Nkx} 2 \cdot 1 \mathrm{mRNA}$ in a developmentally regulated manner and that ex vivo treatment of thyroid glands with bTSH, forskolin, and cAMP analogs increased the expression of Pax8 and $\mathrm{Nkx} 2 \cdot 1 \mathrm{mRNA}$. This is the first report on developmental profiles and hormonal regulation of thyroid gland gene expression in amphibian tadpoles and, together, results reveal a critical role of TSH in the regulation of NIS mRNA expression in the thyroid gland of X. laevis tadpoles.

Journal of Endocrinology (2006) 190, 157-170

\section{Introduction}

Thyroid hormones (THs) are critically important for the regulation of diverse biological processes associated with vertebrate growth, development, and metabolism (Yen 2001). In vertebrates, the de novo synthesis of the two major THs, $3,5,3^{\prime}, 5^{\prime}$-tetraiodothyronine (T4) and 3,5, $3^{\prime}$-triiodothyronine (T3), is restricted to the thyroid gland. Since THs are iodinated thyronine derivatives, active concentration of iodide from the bloodstream represents a crucial step in their biosynthesis. A remarkable capability of the thyroid gland is to concentrate iodide by a factor of $20-40$ over blood plasma iodide concentrations (Dohan et al. 2003). This active uptake of iodide by thyroid follicular cells is an energy-dependent process that is mediated by the sodium-iodide symporter (NIS), a glycoprotein located in the basolateral membrane of thyroid follicular cells (Dohan et al. 2003). The driving force for NIS-mediated iodide transport is the inwardly directed $\mathrm{Na}^{+}$gradient generated by $\mathrm{Na}^{+} \mathrm{K}^{+}$ATPase (Paire et al. 1998). The pivotal role of NIS in mediating thyroidal iodide uptake and thus facilitating $\mathrm{TH}$ synthesis is highlighted by several key findings. Competitive inhibition of NIS-mediated iodide uptake (e.g., by thiocyanate or perchlorate anions) not only blocks thyroidal iodide uptake but impairs TH synthesis (Alexander \& Wolff 1966, Wolff 1998, Tonacchera et al. 2004). In addition, clinical studies of patients with congenital iodide transport defect, a condition characterized by low iodide uptake, hypothyroidism, and goiter, revealed that specific 
mutations of the NIS protein are involved in the etiology of this disease (Pohlenz \& Refetoff 1999, De La Vieja et al. 2000). The first cDNA encoding for rat NIS was cloned in 1996 by Dai et al. (1996). Subsequently, the regulation of NIS mRNA expression in thyroid follicular cells was extensively investigated in various mammalian model systems (reviewed in De La Vieja et al. 2000, Dohan et al. 2003). Together, these studies demonstrated that thyroid-stimulating hormone (TSH) stimulates NIS activity via up-regulation of NIS mRNA and protein expression in thyroid follicular cells (Kogai et al. 1997, Saito et al. 1997a, Selmi-Ruby et al. 2003). Treatment of thyroid follicular cells with forskolin and analogs of cAMP could reproduce the effects of TSH on NIS expression, thus demonstrating that TSH effects are mediated via the cAMPprotein kinase A (PKA) pathway (Saito et al. 1997a, Ohno et al. 1999, Trapasso et al. 1999). Three different transcription factors, including the paired box gene Pax8, the homeodomain-containing protein $\mathrm{Nkx} 2 \cdot 1$ (also called TTF-1 for thyroid transcription factor 1 ) and the forkhead domaincontaining protein FoxE1 (also called TTF-2 for thyroid transcription factor 2) have been implicated in the regulation of thyroid-specific gene expression in mammals (Damante et al. 2001). Although each of these transcription factors is also expressed in other tissues, their co-expression is unique to the thyroid gland. Moreover, functional analyses of NIS promoters in mammalian species strongly suggest important roles for both Pax 8 and $\mathrm{Nkx} 2 \cdot 1$ in the regulation of NIS gene transcription in the thyroid gland (Endo et al. 1997, Ohno et al. 1999, Altmann et al. 2005).

In amphibians, THs play a pivotal role during postembryonic development (metamorphosis), as these hormones are the primary morphogen-regulating diverse processes associated with tissue transformations from a larval to the adult phenotype (Shi 1999). Studies on thyroid system function during amphibian metamorphosis have so far been mainly concerned with the action of $\mathrm{TH}$ in peripheral tissues (Shi 1999), while knowledge about the thyroid gland function during metamorphic development is limited to the description of morphological and biochemical aspects of thyroid gland activity (Regard 1978, Wright et al. 1995). Early studies in amphibians showed that, similar to mammals, treatment with mammalian TSH preparations leads to increased thyroidal iodide uptake (Lynn \& Dent 1961, Hourdry \& Regard 1975), whereas treatment with perchlorate and thiocyanate reduced thyroidal iodide uptake (Lynn \& Dent 1960, Norris \& Platt 1973). The vulnerability of the amphibian thyroid system to perchlorate has also been demonstrated in recent studies showing that long-term treatment of tadpoles with perchlorate inhibits TH-dependent development in Xenopus laevis tadpoles and induces thyroid follicular cell hypertrophy and hyperplasia (Goleman et al. 2002, Tietge et al. 2005). Little attention has so far been given to the molecular analysis of thyroid gland function in amphibians. Recently, cDNAs encoding for $X$. laevis NIS, Pax8, and Nkx2.1 have been cloned (Heller \& Brändli 1999,
Hollemann \& Pieler 2000, Klein et al. 2002), but the expression of the corresponding mRNAs in the thyroid gland of metamorphosing $X$. laevis tadpoles has so far not been examined.

Given the importance of thyroidal iodide uptake for $\mathrm{TH}$ synthesis, the aims of this study were to examine the expression of NIS mRNA during metamorphosis and to characterize the putative role of TSH in the regulation of NIS mRNA in the thyroid gland of X. laevis tadpoles. We show that NIS mRNA is expressed in the thyroid gland of $X$. laevis tadpoles and characterize the developmental expression profile of NIS mRNA during metamorphosis. Experimental induction of goiter by in vivo treatment of tadpoles with sodium perchlorate and ethylenethiourea (ETU) and ex vivo organ culture experiments of $X$. laevis thyroid glands were used as models to reveal the stimulating effects of TSH on thyroidal NIS expression. In addition, developmental and treatment-related changes in mRNA expression were determined for the thyroid transcription factors $\operatorname{Pax} 8$ and $\mathrm{Nkx} 2 \cdot 1$.

\section{Materials and Methods}

\section{Reagents}

Bovine TSH (bTSH) (lot 064K1172, 1.8 IU/mg protein), forskolin, dibutyryl-cAMP (db-cAMP), ETU, sodium perchlorate, dimethylsulfoxide and aminoesterbenzoic acid (MS222) were obtained from Sigma. Dulbecco's modified Eagle's medium (DMEM) was purchased from Invitrogen.

\section{Animals and husbandry}

All experiments were carried out with $X$. laevis tadpoles obtained from in-house breeding of adult animals. During all phases of the in vivo experiments described below, tadpoles were reared in a synthetic culture medium at $22 \pm 1{ }^{\circ} \mathrm{C}$ and $\mathrm{pH} 7 \cdot 0 \pm 0 \cdot 5$ as described previously in Opitz et al. (2005). All rearing tanks were continuously aerated by airstones. A $12 \mathrm{~h}$ light: $12 \mathrm{~h}$ darkness cycle was used. Starting at day 5 postfertilization, tadpoles were fed daily with Sera Micron (Sera, Heinsberg, Germany). Developmental stages of the tadpoles were determined according to the normal table of $X$. laevis (Nieuwkoop \& Faber 1994). All experimental aspects were conducted in compliance with the institutional guidelines for the care and use of animals.

\section{In vivo experiments}

To study the developmental changes in various thyroid system-related parameters, tadpoles at developmental stage 48 were placed in 111 glass aquaria (culture medium volume 10 l) and were raised without any additional treatment until complete tail resorption at stage 66 . The larval density was maintained at 20-25 tadpoles per 101 culture medium. The medium was changed completely three times per week and 
tadpoles were fed daily with Sera Micron. At distinct developmental stages (see Results), tadpoles were collected from the stock population and anesthetized in $100 \mathrm{mg} / \mathrm{l} \mathrm{MS}-$ 222. Pituitary and thyroid glands were dissected and separately collected in $15 \mu \mathrm{l}$ of RNAlater reagent (Qiagen). Tissue samples were stored at $-80{ }^{\circ} \mathrm{C}$ until RNA extraction. In addition, lower jaw tissue was sampled from a subset of tadpoles and fixed in Bouin's solution (Sigma) for thyroid gland histology and morphometry.

For experimental induction of goiter tadpoles, tadpoles at developmental stage 52 were placed in 111 glass aquaria (volume of test solution was $10 \mathrm{l}$ ) containing $20 \mathrm{mg} / \mathrm{l}$ sodium perchlorate, $50 \mathrm{mg} / 1 \mathrm{ETU}$, and culture medium alone (controls). The test solutions were replaced completely three times per week and tadpoles were fed daily with Sera Micron. After treatment for a total of 12 days, tadpoles were anesthetized in $100 \mathrm{mg} / \mathrm{l} \mathrm{MS}-222$ and pituitaries and thyroid glands were collected in RNAlater reagent. Lower jaw tissue was collected from a subset of test animals and fixed in Bouin's solution for thyroid gland histology.

\section{Organ culture}

Before tissue removal for organ culture, stage 56/57 tadpoles were immersed in the in vivo culture medium supplemented with $200 \mu \mathrm{g} / \mathrm{ml}$ streptomycin (Cambrex, Verviers, Belgium) and $200 \mathrm{U} / \mathrm{ml}$ penicillin (Cambrex) for $24 \mathrm{~h}$. Tadpoles were not fed during the $24 \mathrm{~h}$ treatment with antibiotics. All procedures related to the subsequent ex vivo culture of thyroid glands were done under sterile conditions in a tissue culture hood and the protocol used was based on the technique described by Denver (1988), with some modifications. DMEM was diluted to two-thirds strength and supplemented with $0 \cdot 1 \% \mathrm{BSA}$ (Invitrogen), $1 \cdot 1 \mathrm{mM} \mathrm{L}$-glutamine (Cambrex), $50 \mathrm{U} / \mathrm{ml}$ penicillin, $50 \mu \mathrm{g} / \mathrm{ml}$ streptomycin and $50 \mathrm{U} /$ $\mathrm{ml}$ neomycin (Sigma). Tadpoles were anesthetized in $100 \mathrm{mg} / 1$ MS-222 and decapitated. Following removal of the cranium and the upper jaw, the lower jaw was briefly rinsed in sterile distilled water and ethanol (70\%). Ventral skin and muscle tissue were removed and the paired thyroids were dissected out together with a small piece of the underlying hyoid bone. Thyroid glands were then rinsed in $1 \mathrm{ml}$ ice-cold DMEM for $1 \mathrm{~h}$, transferred to $1 \mathrm{ml}$ fresh ice-cold DMEM and allowed to warm up to room temperature within $1 \mathrm{~h}$. Thereafter, thyroid glands were individually placed into wells of 24-well culture plates (Sarstedt, Nümbrecht, Germany) containing $500 \mu \mathrm{l}$ fresh DMEM and were incubated at $25^{\circ} \mathrm{C}$ for $16 \mathrm{~h}$. After preincubation, the medium was replaced with $500 \mu \mathrm{l}$ fresh DMEM or $500 \mu \mathrm{l}$ DMEM containing bTSH $(0 \cdot 1,1 \cdot 0$, $10 \mathrm{mU} / \mathrm{ml}$ ), $10 \mu \mathrm{M}$ forskolin, $0 \cdot 1 \%$ dimethylsulfoxide (solvent control for forskolin treatment) or $2 \mathrm{mM} \mathrm{db}$-cAMP. Depending on the experimental setup (see Results), incubation of thyroid glands with the test chemicals was continued for up to $48 \mathrm{~h}$, with media changes performed every $24 \mathrm{~h}$. In some experiments, thyroid glands were co-incubated with freshly dissected pituitary glands from stage 58 tadpoles. The pituitary glands were freshly dissected 2 to $3 \mathrm{~h}$ before the end of the $16 \mathrm{~h}$ preincubation of thyroid glands, rinsed as described for the thyroid glands and placed into wells containing preincubated thyroid glands in $500 \mu \mathrm{l}$ fresh DMEM. Thyroid and pituitary tissues were co-cultured for $24 \mathrm{~h}$. At the end of each incubation period, thyroid gland tissue was separated from hyoid bone tissue, collected in $15 \mu$ of RNAlater reagent and stored at $-80^{\circ} \mathrm{C}$ until RNA extraction.

\section{Semi-quantitative RT-PCR}

Extraction of RNA was performed for individual thyroid gland and pituitary tissue samples, with the exception of stage 51 tadpoles, where tissue samples from two animals were always pooled before RNA extraction. Total RNA was extracted using RNeasy Micro Kit (Qiagen) including the use of carrier RNA and on-column treatment with RNase-free DNase (Qiagen) according to the manufacturer's protocol. Total RNA content was measured using the RiboGreen RNA quantitation kit (Invitrogen) according to the manufacturer's protocol in a Spectrafluor plus microplate reader (Tecan, Crailsheim, Germany). cDNA was reverse transcribed from $100 \mathrm{ng}$ total RNA using $3 \cdot 5 \mathrm{pmol}$ oligo(dT) primer (Biometra, Göttingen, Germany), $7 \cdot 5 \mathrm{nmol}$ of each dNTP (Biometra), and 5 units Avian Myeloblastosis Virus RT (Biometra). The cDNA was diluted 1:16 prior to PCR amplification in a thermal cycler (Biometra). PCR was performed in a $25 \mu \mathrm{l}$ reaction using $2 \mu \mathrm{l}$ of cDNA solution as template. PCRs contained $2 \mathrm{nmol}$ of each dNTP (Biometra), $10 \mathrm{pmol}$ of each PCR primer (TibMolBiol, Berlin, Germany) and 1 unit of Taq DNA Polymerase (Invitrogen). Thermal cycler protocols included initial denaturation at $94{ }^{\circ} \mathrm{C}$ for 3 min followed by cycles of denaturation $\left(94^{\circ} \mathrm{C}\right.$ for $30 \mathrm{~s})$, annealing $(30 \mathrm{~s})$, and extension $\left(72^{\circ} \mathrm{C}, 40 \mathrm{~s}\right)$ and a final extension step $\left(72^{\circ} \mathrm{C}, 10 \mathrm{~min}\right)$. The nucleotide sequences of the primers, cycle numbers, and annealing temperatures used in PCR are listed in Table 1. Amplified PCR products $(7 \mu \mathrm{l}$ per sample) were electrophoresed on a $1.8 \%$ agarose gel and stained with ethidium bromide (Gibco). Images of ethidium bromide-stained gels were taken using the GelDoc 2000 system (BioRad) and densitometric analyses were performed with Quantity One software (BioRad). Densitometric values for elongation factor $1 \alpha(\mathrm{EF})$ were used to normalize NIS, Pax8, Nkx2 1 , and TSH $\beta$ values for variations in cDNA loading. Results from triplicate analyses of individual RNA samples for target gene expression were averaged, yielding a single value for each RNA sample to be used in the statistical analysis. PCR products were extracted from agarose gels using QIAquick kit (Qiagen), and the identity of the PCR products was confirmed by sequence analysis (Sequence Laboratories, Göttingen, Germany).

\section{Thyroid gland histology and morphometry}

Lower jaw tissue samples containing the paired thyroid gland were dehydrated in a graded series of alcohol, embedded in paraffin and sectioned in a transverse plane from dorsal to ventral at $5 \mu \mathrm{m}$ thickness. Serial sections were mounted on glass slides and stained with hematoxylin and eosin. For each 
Table 1 Gene-specific primer sets and thermal cycler conditions for PCR analysis

\begin{tabular}{|c|c|c|c|c|c|}
\hline & GenBank Accession no. & Forward $(F)$ and reverse $(R)$ primer & $\boldsymbol{T}_{\mathbf{A}}\left({ }^{\circ} \mathrm{C}\right)$ & Cycles & Product size $(b p)$ \\
\hline \multicolumn{6}{|l|}{ Gene } \\
\hline $\begin{array}{l}\text { Sodium-iodide } \\
\text { symporter }\end{array}$ & ВС077614 & $\begin{array}{l}\text { F: TAAACgggAgACAATAgCAC } \\
\text { R: TgggCCTCATACTCCTCTT }\end{array}$ & 58 & $31-33$ & 585 \\
\hline Pax8 & AJ010504 & $\begin{array}{l}\text { F: gCgCTAgCTCСАССССТTCA } \\
\text { R: gCgCСАAСТgТСТССgТАTgСТ }\end{array}$ & 58 & $30-32$ & 307 \\
\hline $\mathrm{Nkx} 2 \cdot 1$ & AF250347 & $\begin{array}{l}\text { F: CggCggAATgAACATggAAggTCT } \\
\text { R: ggAgggCggCTgTgggTgTATTAg }\end{array}$ & 58 & $29-31$ & 409 \\
\hline Elongation factor $1 \alpha$ & M25504 & $\begin{array}{l}\text { F: TgCCATTgTTgACATgATCCC } \\
\text { R: TACTATTAAACTCTgATggCC }\end{array}$ & 59 & $22-24$ & 285 \\
\hline
\end{tabular}

$T_{\mathrm{A}}$, annealing temperature.

tadpole, five sections of the central portion of the right thyroid lobe were histologically examined and epithelial cell height measurements were performed as described in Opitz et al. (2006a). A single mean value for epithelial cell height was calculated for each animal, and a total of five tadpoles were analyzed at each developmental stage.

\section{Statistical analysis}

Epithelial cell heights and densitometric data from RT-PCR assays were log-transformed to satisfy the criteria of normality and homogeneity of variance. Densitometric data were then analyzed by Dunnett's test to compare control data to all other treatment groups or by Tukey-Kramer's multiple comparison test for pair-wise comparisons to identify significant differences among experimental groups. Developmental stage data were analyzed using the nonparametric Kruskal-Wallis test followed by Dunn's multiple comparison test to determine whether significant differences existed between the developmental stage composition of treatment groups. Statistical analyses were performed using the software package Sigma Stat $2 \cdot 0$ (SPSSJandel Scientific, Erkrath, Germany). Differences were considered significant at $P<0 \cdot 05$.

\section{Results}

Determination of NIS, Pax8, and Nkx2. $1 \mathrm{mRNA}$ by RT-PCR

Using total RNA, isolated from thyroid gland tissue of stage $57 / 58$ tadpoles, PCR products of the expected length were detected by gel electrophoresis following RT-PCR with primers designed for amplification of NIS (585 bp), Pax8 (307 bp), Nkx2 1 (409 bp), and EF (285 bp) cDNAs (Fig. 1). Sequence analysis of the PCR products confirmed the successful amplification of all four transcripts from thyroid gland RNA. To further validate our RT-PCR protocols, total RNA isolated from different tissues of stage $57 / 58$ tadpoles was analyzed for expression of NIS, Pax $8, \mathrm{Nkx} 2 \cdot 1$, and EF mRNA by qualitative RT-PCR. Figure 1 shows that extrathyroidal NIS mRNA expression was detected in stomach and kidney tissue but not in liver, heart, or lung tissue. Among the tissues analyzed, extrathyroidal expression of Pax 8 and $\mathrm{Nkx} 2 \cdot 1 \mathrm{mRNA}$ was limited to kidney and lung tissue respectively, whereas EF mRNA was successfully detected in all tissues examined (Fig. 1). For semi-quantitative RT-PCR analysis of NIS, Pax8, Nkx2 1 mRNAs in thyroid and TSH $\beta$ mRNA in pituitary, PCR cycle numbers were then empirically determined to ensure detection within the log-linear range of the PCR (Fig. 2). Preliminary experiments showed a wide range of thyroidal NIS mRNA expression and, therefore, cycle experiments were separately performed with cDNA obtained from tissue samples displaying low and high expression levels of NIS in order to determine cycle numbers at which log-linear phases overlap (Fig. 2C). Optimized assay conditions finally applied in the semiquantitative RT-PCR experiments are summarized in Table 1.

\section{Developmental profiles of NIS, Pax8, and Nkx2. $1 \mathrm{mRNA}$}

The developmental profiles of NIS, Pax8, and $\mathrm{Nkx} 2 \cdot 1$ mRNA expression were studied in thyroid glands of tadpoles

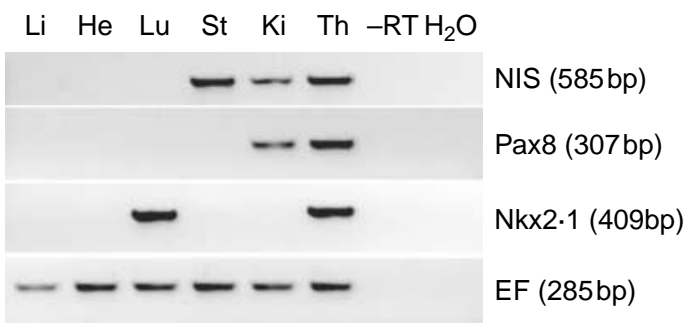

Figure 1 Qualitative RT-PCR analysis of sodium-iodide symporter (NIS), Pax $8, \mathrm{Nkx} 2 \cdot 1$, and elongation factor $1 \alpha(\mathrm{EF}) \mathrm{mRNA}$ expression in different tissues of stage 57/58 tadpoles. Total RNA was extracted from liver $(\mathrm{Li})$, heart $(\mathrm{He})$, lung $(\mathrm{Lu})$, stomach $(\mathrm{St})$, kidney $(\mathrm{Ki})$ and thyroid $(\mathrm{Th})$ tissue and analyzed by nonquantitative RT-PCR (over-amplification to plateau) for NIS (36 cycles), Pax8 (35 cycles), and Nkx2 1 ( 34 cycles). EF ( 23 cycles) served as control of the loading amount of total RNA from each tissue. PCR products were separated on a $1 \cdot 8 \%$ agarose gel stained with ethidium bromide. Negative controls included RT-PCR experiments with thyroid RNA in which enzyme was omitted $(-\mathrm{RT})$ and the use of water as template for PCR amplification $\left(\mathrm{H}_{2} \mathrm{O}\right)$. 

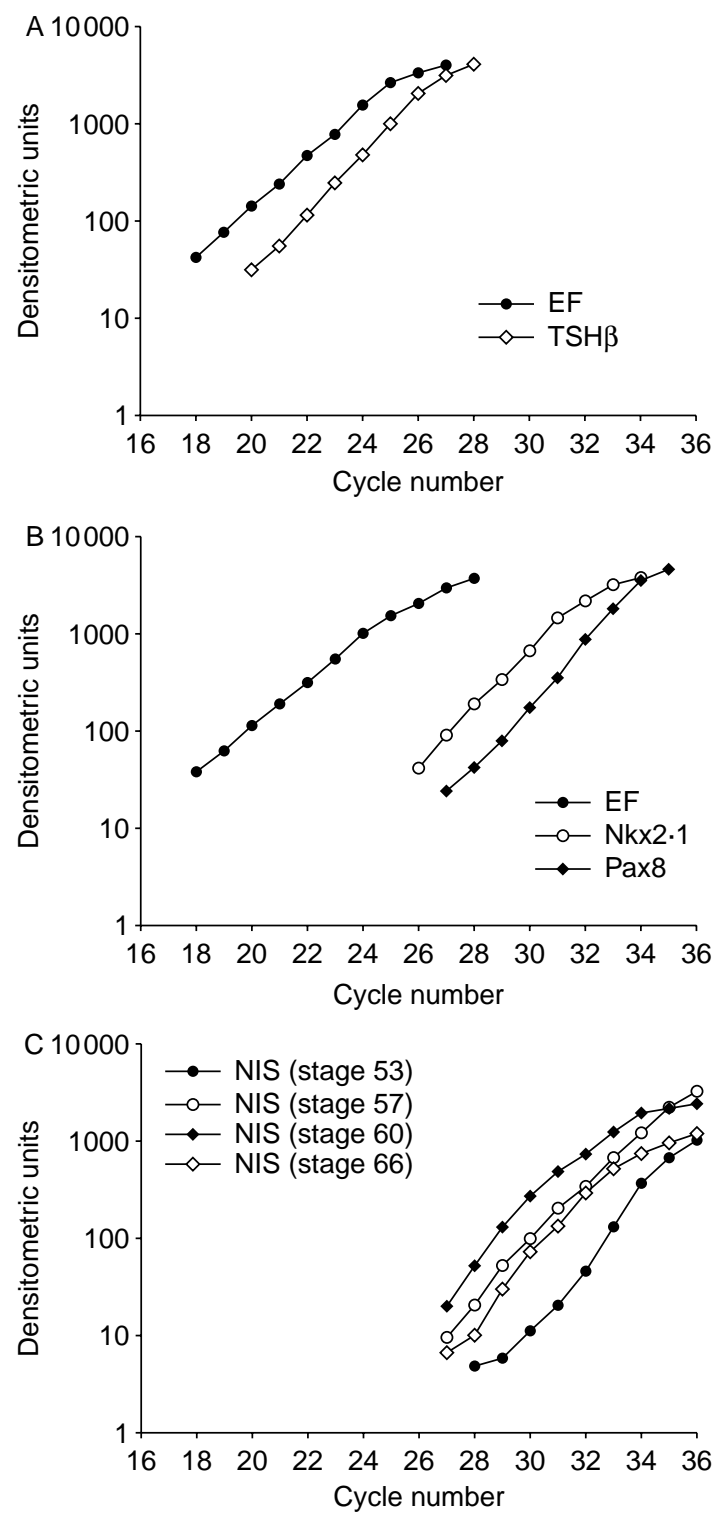

Figure 2 Determination of the log-linear phase of PCR with genespecific primers for sodium-iodide symporter (NIS), Pax8, Nkx2 1 , TSH $\beta$ subunit, and elongation factor $1 \alpha$ (EF). PCR was performed as described in Materials and Methods with cDNA generated from pituitary (A) and thyroid tissue (B) of stage 57/58 tadpoles. For NISspecific PCR (C), cDNA of thyroid tissue from tadpoles at different developmental stages was used to determine overlap of log-linear amplification phases. Each cycle experiment was performed in triplicate. Mean values are shown and standard error bars are omitted to reduce clutter.

beginning at premetamorphic stage 51 throughout the end of metamorphosis at stage 66 (Fig. 3). Expression of NIS mRNA in the thyroid gland was low in premetamorphic tadpoles (stages 51-53). A first statistically significant increase of NIS mRNA expression was detected between late premetamorphic stage 53 and the onset of prometamorphosis at $\begin{array}{lllllllllll}\text { A } & \text { Stage } & 51 & 53 & 54 & 56 & 58 & 60 & 62 & 64 & 66\end{array}$

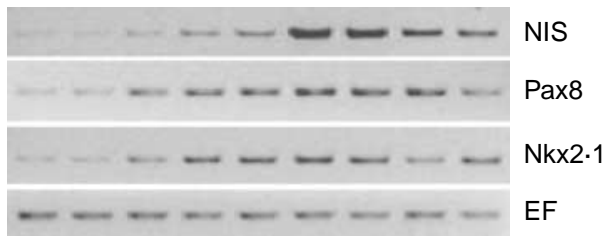

B
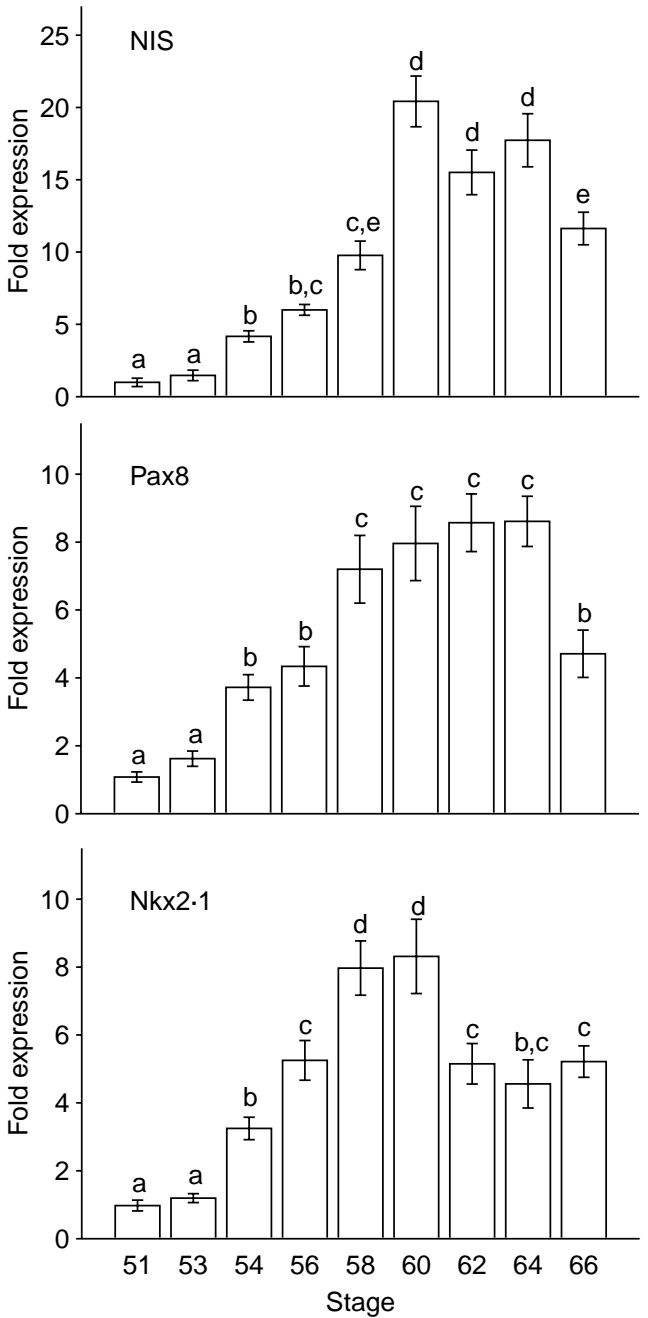

Figure 3 Developmental mRNA expression profiles of sodiumiodide symporter (NIS), Pax8, $\mathrm{Nkx} 2 \cdot 1$, and elongation factor $1 \alpha(\mathrm{EF})$ in thyroid glands of Xenopus laevis tadpoles during spontaneous metamorphosis. Total RNA was extracted from thyroid gland tissue sampled at the indicated stages of development (Nieuwkoop \& Faber 1994) and analyzed by semi-quantitative RT-PCR. PCR products were separated on a $1 \cdot 8 \%$ agarose gel stained with ethidium bromide. (A) Representative agarose gel images of amplified cDNA fragments for each gene. (B) Results from densitometric analyses of scanned agarose gels. NIS, Pax8, and Nkx2 1 values were normalized by EF values. For graphical presentation, results were expressed relative to the expression level determined at stage 51 (arbitrarily set at 1-0). Data are shown as mean \pm s.E. $(n=6$ RNA samples per stage). Within each graph shown, different letters denote means that are significantly different $(P<0 \cdot 05$; Tukey-Kramer multiple comparison test). 
stage $54(P<0 \cdot 05)$. The signal intensity of the separated bands increased further during prometamorphosis, reaching peak levels at climax stage 60. A sharp and highly significant increase in NIS mRNA expression was observed between stages 58 and $60 \quad(P<0 \cdot 001)$. NIS mRNA expression remained high during metamorphic climax and pairwise multiple comparison tests did not detect significant differences in the expression between stages 60 and 64 . However, between stages 64 and 66, NIS mRNA expression showed a distinct and significant decline $(P<0 \cdot 01)$ to levels comparable to prometamorphic stage 58 . Similar to NIS, only weak mRNA expression was determined for the transcription factors Pax8 and Nkx2.1 at premetamorphic stages 51 and 53 (Fig. 3). A significant up-regulation of mRNA expression was detected for both genes at stage $54(P<0 \cdot 01)$. Pax8 mRNA expression was maximal between late prometamorphic stage 58 and late climax stage 64 but dropped significantly between stages 64 and $66(P<0 \cdot 01)$. Nkx2 1 mRNA expression was maximal between late prometamorphic stage 58 and early climax stage 60 but decreased significantly between stage 60 and stage $62(P<0 \cdot 05)$ and expression remained at a reduced level throughout the remaining climax phase.

\section{Developmental profiles of thyroid follicular cell height}

In addition to the determination of developmental mRNA expression profiles in the thyroid gland, a subset of animals was analyzed morphometrically at distinct developmental stages for changes in the thyroid follicular cell height as a histological maker of thyroid follicular cell activity (Kalisnik 1972). The height of thyroid follicular cells showed a distinct developmental profile throughout metamorphosis (Fig. 4A). At premetamorphic stages, follicular cells had a cuboidal shape and a mean cell height of $5 \cdot 5 \pm 1 \cdot 1 \mu \mathrm{m}$. Pairwise multiple comparison tests showed that the cell height increased significantly at the onset of prometamorphosis $(9 \cdot 2 \pm$ $2 \cdot 0 \mu \mathrm{m}$ at stage $54, P<0 \cdot 05)$ followed by a constant but less pronounced increase to peak values at early climax stages $(11 \cdot 5 \pm 2 \cdot 8 \mu \mathrm{m}$ at stage 60$)$. A slight decrease in follicular cell height was noted at stage $64(11 \cdot 0 \pm 2 \cdot 3 \mu \mathrm{m})$ and the completion of metamorphosis at stage $66(9 \cdot 4 \pm 2 \cdot 3 \mu \mathrm{m})$.

\section{Developmental profile of TSH $\beta$ mRNA}

Thyroid gland activity is primarily stimulated by TSH, which is produced and secreted by thyrotropic cells of the pituitary (Vassart \& Dumont 1992). In order to relate our observations on developmental expression profiles of genes in the thyroid gland to changes in pituitary TSH synthesis, we additionally determined the mRNA expression of TSH $\beta$ in the pituitary tissue collected from the same animals being sampled for thyroid gland gene expression analyses (Fig. 4B and C). Expression of TSH $\beta$ mRNA was low in premetamorphic tadpoles (stages 51-53) but increased markedly between prometamorphic stages 54 and 56 . Levels of TSH $\beta$ mRNA increased further during prometamorphosis and reached peak
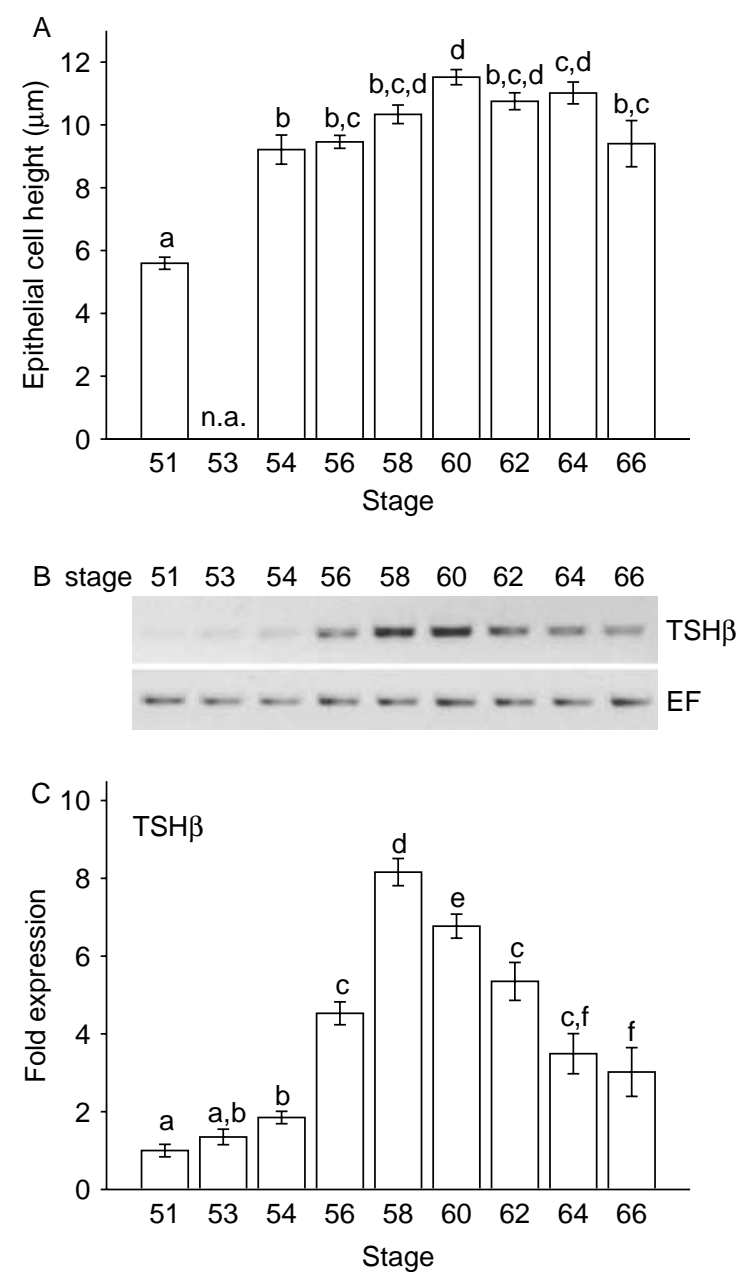

Figure 4 Developmental changes in thyroid epithelial cell height and mRNA expression of thyroid-stimulating hormone $\beta$-subunit $(\mathrm{TSH} \beta$ ) during spontaneous metamorphosis. (A) Results from morphometric analyses of thyroid gland tissue sampled at the indicated stages (Nieuwkoop \& Faber 1994). Note that epithelial cell height was not analyzed (n.a.) for stage 53 tadpoles. Columns and bars represent means and S.D. ( $n=5$ animals per stage). For determination of TSH $\beta$ mRNA expression, total RNA was extracted from pituitaries sampled at the indicated stages of development and analyzed by semi-quantitative RT-PCR. PCR products were separated on a $1 \cdot 8 \%$ agarose gel stained with ethidium bromide. (B) Representative agarose gel images of amplified cDNA fragments for TSH $\beta$ and elongation factor $1 \alpha(E F)$. (C) Results from densitometric analyses of scanned agarose gels. TSH $\beta$ values were normalized by EF values. For graphical presentation, results were expressed relative to the expression level determined at stage 51 (arbitrarily set at $1 \cdot 0)$. Data are given as mean \pm s.E. $(n=6$ RNA samples per stage). Within each graph shown, different letters denote means that are significantly different $(P<0 \cdot 05$; TukeyKramer multiple comparison test).

values at late prometamorphic stage 58 (approximately eightfold higher than stage 51). From stage 60 towards the end of metamorphosis, there was a steady decrease in TSH $\beta$ mRNA expression and at stage 66, the expression level was 
intermediate to levels observed at prometamorphic stages 54 and 56.

Effects of ETU and perchlorate treatment on thyroid gland gene expression

The goitrogen treatment model has been successfully used in various mammalian studies to elucidate $\mathrm{TSH}$-dependent changes in thyroidal gene expression (Uyttersprot et al. 1997, Viglietto et al. 1997, Suzuki et al. 1999). Stage 52 tadpoles were treated with $50 \mathrm{mg} / 1 \mathrm{ETU}$ or $20 \mathrm{mg} / 1$ sodium perchlorate for 12 days to study in vivo the effects of TSH overexpression on gene expression in the thyroid gland. Because ETU inhibits iodide organification (Doerge \& Takazawa 1990) and perchlorate inhibits thyroidal iodide uptake (Wolff 1998), these treatments were both expected to inhibit TH synthesis, thereby inducing a compensatory rise in $\mathrm{TSH}$ production and release. The presence of TH-deficient conditions in the treated tadpoles was assessed via examination of tadpole development, TSH $\beta$ mRNA expression in pituitary tissue, and thyroid gland histology (Figs 5 and 6). Whereas untreated control tadpoles showed development to stage 57/58 within 12 days, tadpoles exposed to either ETU or sodium perchlorate were developmentally arrested at stage 55 (Fig. 5A). Analysis of TSH $\beta$ mRNA expression in pituitary tissue by semi-quantitative RT-PCR demonstrated $2 \cdot 1$ - and $2 \cdot 0$-fold higher TSH $\beta$ expression in sodium perchlorate and ETU-treated tadpoles respectively, compared to the controls (Fig. 5B and C). In the ETU and perchlorate treatment groups, gross morphological examination showed a marked enlargement of the thyroid gland and histological analysis of thyroid gland sections revealed marked hypertrophy and hyperplasia of follicular epithelial cells in ETUand perchlorate-treated tadpoles (Fig. 6). When total RNA of thyroid glands was analyzed by semi-quantitative RT-PCR for changes in gene expression (Fig. 7), a strong up-regulation of NIS mRNA was detected in tadpoles treated with sodium perchlorate $(\sim 21$-fold $)$ and ETU ( 18 -fold) compared to controls (Fig. 7B). The up-regulation was significant $(P<0 \cdot 001)$ and highly consistent among individuals from each of the two goitrogen treatment groups. In contrast, no significant differences in the expression of Pax8 and Nkx2 1 mRNA were detectable between the treatment groups (Fig. 7C and D).

\section{Organ culture experiments}

To gain further insight into the hormonal regulation of NIS mRNA expression in the thyroid gland, we devised a series of organ culture experiments with thyroid glands collected from stage 56/57 tadpoles. In all organ culture experiments conducted during this study, a rapid decline in basal NIS mRNA expression levels was observed during the $16 \mathrm{~h}$ preincubation period of thyroid glands that was performed after organ dissection. After preincubation, NIS mRNA was barely detectable by RT-PCR in cultured control thyroid glands (Fig. 8A). Thyroid glands incubated for $48 \mathrm{~h}$ in DMEM containing various concentrations of bTSH $(0 \cdot 1-10 \mathrm{mU} / \mathrm{ml})$ revealed strong up-regulation of NIS mRNA by $1 \cdot 0$ and $10 \mathrm{mU} / \mathrm{ml} \mathrm{bTSH}$ but not at the lowest concentration of $0 \cdot 1 \mathrm{mU} / \mathrm{ml} \mathrm{bTSH}$ (Fig. 8B). In contrast to NIS, expression of Pax 8 and $\mathrm{Nkx} 2 \cdot 1$ mRNA was always detectable in
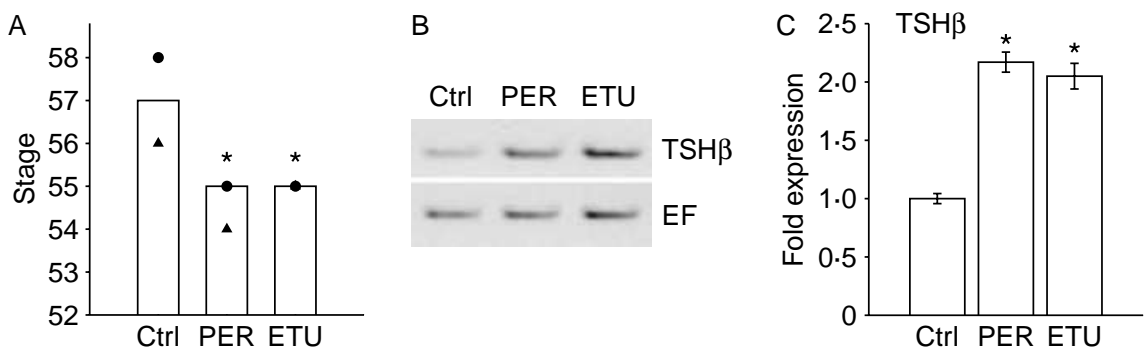

Figure 5 Effects of treatment of stage 52 Xenopus laevis tadpoles with $20 \mathrm{mg} / \mathrm{l}$ sodium perchlorate (PER) and $50 \mathrm{mg} / \mathrm{l}$ ethylenethiourea (ETU) on development and thyroid-stimulating hormone $\beta$-subunit (TSH $\beta$ ) mRNA expression. (A) The distribution of developmental stages (Nieuwkoop \& Faber 1994) in the different treatment groups at day 12 ( $n=15$ tadpoles per treatment). Columns represent median values, and maximum (circles) and minimum (triangles) stages observed in each treatment group are indicated. Statistically significant differences from the control group (Ctrl) are marked by asterisks ( $P<0 \cdot 05$, Dunn's test). For RT-PCR determination of TSH $\beta$ mRNA expression, total RNA was extracted from eight individual pituitaries per treatment group sampled on treatment day 12 . PCR products were separated on a $1 \cdot 8 \%$ agarose gel stained with ethidium bromide. (B) Representative agarose gel images of amplified cDNA fragments for TSH $\beta$ and elongation factor $1 \alpha(E F)$. (C) Results from densitometric analyses of scanned agarose gels. TSH $\beta$ values were normalized by EF values. For graphical presentation, results were expressed relative to control group values (arbitrarily set at $1 \cdot 0)$. Data are shown as mean \pm s.E. $(n=8$ RNA samples per treatment). Statistically significant differences in TSH $\beta$ mRNA expression from the control group are marked by asterisks $(P<0 \cdot 05$, Dunnett's test). 

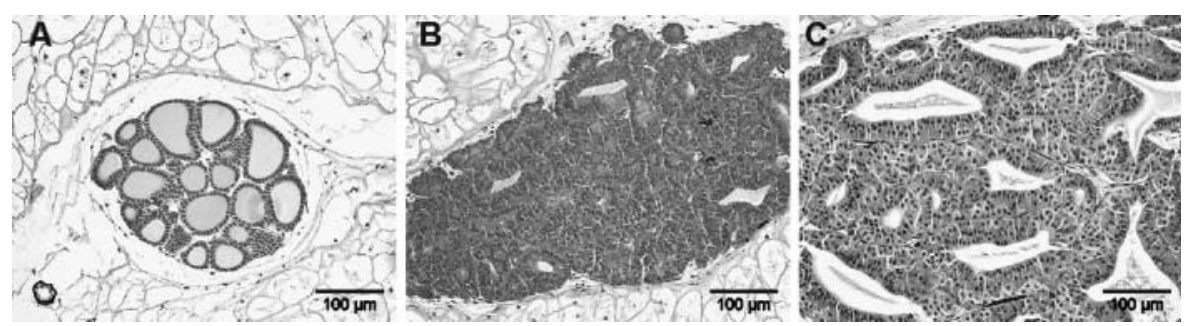

Figure 6 Histological changes in thyroid glands of Xenopus laevis tadpoles after treatment with $20 \mathrm{mg} / \mathrm{l}$ sodium perchlorate (PER) and $50 \mathrm{mg} / \mathrm{l}$ ethylenethiourea (ETU). Treatment of tadpoles was initiated at stage 52 (Nieuwkoop \& Faber 1994), and thyroid gland histology was examined after 12 days of treatment. In comparison to the control group (A), tadpoles treated with PER (B) and ETU (C) showed remarkable enlargement of thyroid glands displaying follicular cell hypertrophy and hyperplasia. In PER-treated tadpoles, collapsed follicles devoid of colloid and lined by high columnar epithelia predominated while glands from ETU-treated tadpoles displayed distended follicles with enlarged lumina containing small amounts of foamy colloid. Sections of $5 \mu \mathrm{m}$ thickness were stained with hematoxylin and eosin, and light micrographs were taken at $20 \times$ magnification.

cultured thyroid glands by RT-PCR. Treatment of cultured glands with 1.0 and $10 \mathrm{mU} / \mathrm{ml} \mathrm{bTSH}$ caused a moderate increase in the expression of both genes (approximately twofold), whereas $0.1 \mathrm{mU} / \mathrm{ml} \mathrm{bTSH}$ failed to affect the
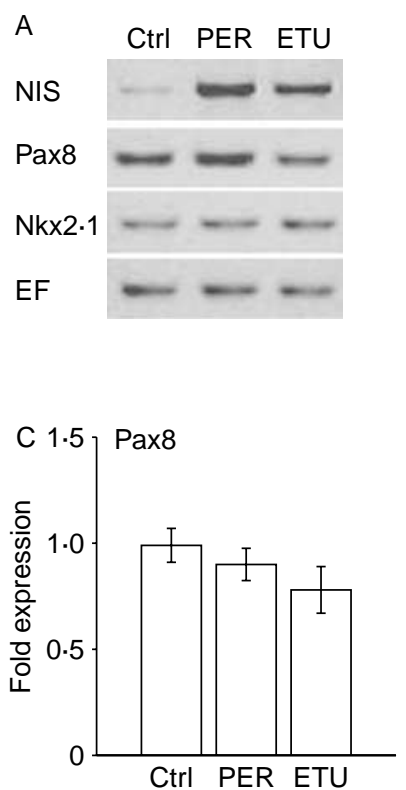

expression of both transcription factors (Fig. 8C and D). A concentration of $1.0 \mathrm{mU} / \mathrm{ml} \mathrm{bTSH}$ was then used to study the time-course of bTSH effects on NIS mRNA expression during $48 \mathrm{~h}$ of thyroid gland culture. As illustrated in Fig. 9,
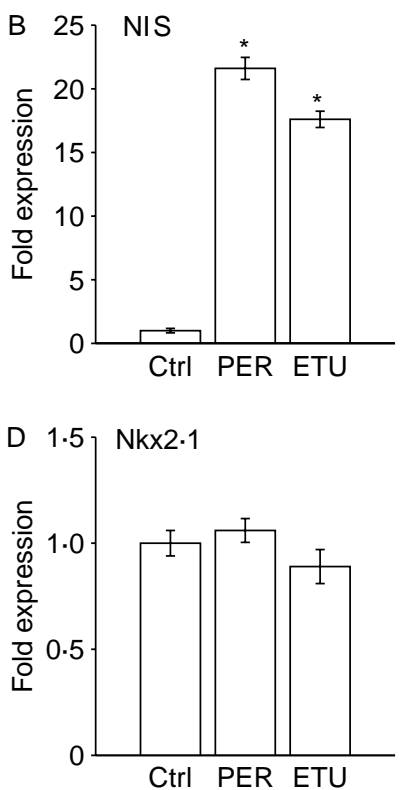

Figure 7 Effects of treatment of Xenopus laevis tadpoles with $20 \mathrm{mg} / \mathrm{l}$ sodium perchlorate (PER) and $50 \mathrm{mg} / \mathrm{l}$ ethylenethiourea (ETU) on thyroid gland gene expression. Total RNA was extracted from eight individual thyroid glands per treatment group sampled on treatment day 12. Expression of sodium-iodide symporter (NIS), Pax8, Nkx2·1 mRNA, and elongation factor $1 \alpha(\mathrm{EF})$ was analyzed by semiquantitative RT-PCR and PCR products were separated on a $1 \cdot 8 \%$ agarose gel stained with ethidium bromide. (A) Representative agarose gel images of amplified cDNA fragments for each gene. (B-D) Results from densitometric analyses of scanned agarose gels. Densitometric values for NIS, Pax8, and Nkx2 1 were normalized by EF values. For graphical presentation, results were expressed relative to control group (Ctrl) values (arbitrarily set at $1 \cdot 0)$. Data are given as mean \pm S.E. $(n=8$ RNA samples per treatment). Statistically significant differences from the control group are marked by asterisks $(P<0 \cdot 05$, Dunnett's test). 
A

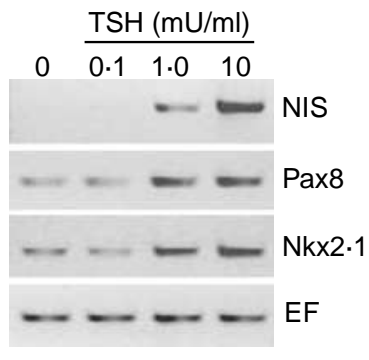

C

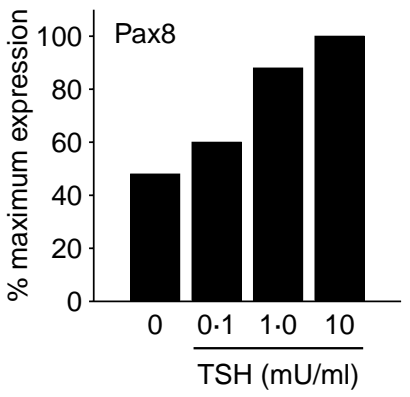

B

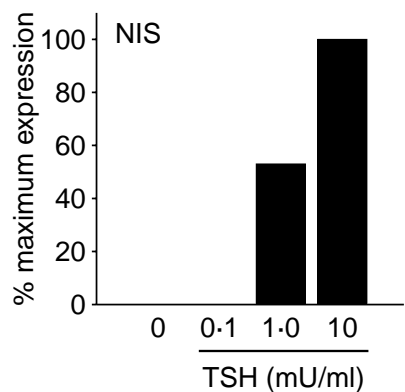

$\mathrm{D}$

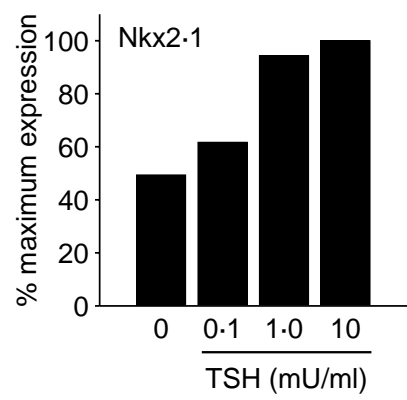

Figure 8 Effects of various concentrations of bovine TSH (bTSH) $(0 \cdot 1-10 \mathrm{mU} / \mathrm{ml})$ on mRNA expression of sodium-iodide symporter (NIS), Pax8 and $\mathrm{Nkx2} \cdot 1$ in cultured thyroid glands of Xenopus laevis tadpoles. The paired thyroid glands were dissected from stage 56/57 tadpoles, preincubated for $16 \mathrm{~h}$ in TSH-free medium and treated with the indicated TSH concentration for a total of $48 \mathrm{~h}$. Total RNA was extracted from thyroid gland tissue and analyzed by semi-quantitative RT-PCR for target gene expression. PCR products were separated on a $1 \cdot 8 \%$ agarose gel stained with ethidium bromide.

(A) Representative agarose gel images of amplified cDNA fragments for each gene. (B-D) Results from densitometric analyses of scanned agarose gels. Densitometric values for NIS, Pax8 and Nkx2 1 were normalized by elongation factor $1 \alpha$ values (EF). For graphical presentation, results were expressed as a percentage of the experimental group with the highest expression level (arbitrarily set at 100\%). Results from two independent experiments (each containing at least three replicates per treatment) were averaged. Note that NIS mRNA expression could not be reproducibly detected in the 0 and $0 \cdot 1 \mathrm{mU} / \mathrm{ml} \mathrm{TSH}$ treatment groups.

while NIS mRNA was not detectable in untreated glands, induction of NIS mRNA expression was seen as early as $6 \mathrm{~h}$ after initiation of bTSH treatment. Peak expression of NIS mRNA was observed after $12 \mathrm{~h}$ of bTSH treatment, but NIS mRNA expression was still maintained at elevated levels throughout the $48 \mathrm{~h}$ of organ culture. In another set of experiments, thyroid glands were co-incubated for $24 \mathrm{~h}$ with freshly dissected pituitary glands of stage $58 \mathrm{X}$. laevis tadpoles or $1.0 \mathrm{mU} / \mathrm{ml} \mathrm{bTSH}$. Results shown in Fig. $10 \mathrm{~A}$ demonstrate that co-culture of thyroid glands with pituitary glands could fully reproduce the effects of $1.0 \mathrm{mU} / \mathrm{ml} \mathrm{bTSH}$ on NIS mRNA expression. In order to examine whether the effects of TSH on NIS mRNA expression are mediated via the cAMP-PKA pathway, thyroid glands were cultured for $48 \mathrm{~h}$ in the presence of $\mathrm{bTSH}(1.0 \mathrm{mU} / \mathrm{ml})$, forskolin $(10 \mu \mathrm{M})$ or $\mathrm{db}$-cAMP $(2 \mathrm{mM})$, and the expression of NIS

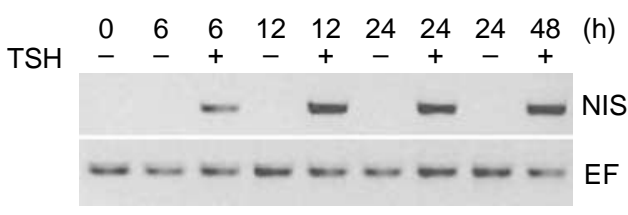

Figure 9 Ethidium bromide-stained gels showing RT-PCR analysis of sodium-iodide symporter (NIS) and elongation factor $1 \alpha$ (EF) expression in cultured Xenopus laevis thyroid glands after various incubation times. The paired thyroid glands were dissected from stage 56/57 tadpoles and preincubated for $16 \mathrm{~h}$ in TSH-free medium. Total RNA was extracted from thyroid glands cultured thereafter for the indicated periods of time in the absence or presence of $1 \mathrm{mU} / \mathrm{ml} \mathrm{TSH}$. Two independent experiments (each containing three replicates per experimental group) were performed with tadpoles from different spawns and yielded similar results. Note that NIS mRNA expression could not be detected in the control group. 
A

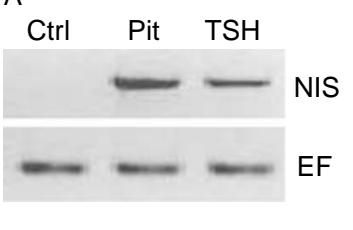

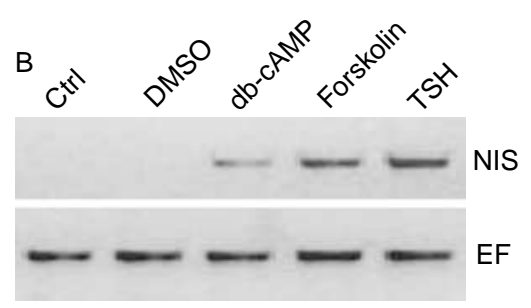

Figure 10 Ethidium bromide-stained gels showing RT-PCR analysis of sodium-iodide symporter (NIS) and elongation factor $1 \alpha$ (EF) expression in cultured Xenopus laevis thyroid glands after pituitary (Pit) co-culture for $24 \mathrm{~h}$ (A) or treatment with dibutyryl-cAMP (db-cAMP) and forskolin for $48 \mathrm{~h}$ (B). The paired thyroid glands were dissected from stage $56 / 57$ tadpoles and preincubated for $16 \mathrm{~h}$ in TSH-free medium. Thereafter, glands were co-incubated with freshly dissected pituitaries (pit) from stage 58 tadpoles or treated with $2 \mathrm{mM} \mathrm{db}$-cAMP and $10 \mu \mathrm{M}$ forskolin. Thyroid glands incubated in the absence (Ctrl) or presence of $1 \mathrm{mU} / \mathrm{ml}$ bovine TSH served as negative and positive controls in these experiments respectively. A treatment group with $0 \cdot 1 \%$ dimethylsulfoxide (DMSO) served as a solvent control for the forskolin treatment. Data are representative of two independent experiments (each containing three replicates per experimental group) respectively.

mRNA was determined by semi-quantitative RT-PCR. Figure 10B shows that treatment of thyroid glands with forskolin or db-cAMP could reproduce the NIS-inducing effect of $1.0 \mathrm{mU} / \mathrm{ml} \mathrm{bTSH}$.

\section{Discussion}

THs are the primary morphogen initiating and regulating tissue remodeling during amphibian metamorphosis (Shi 1999). During premetamorphosis (stages 36/37 to 53 in X. laevis), the thyroid gland still undergoes development into a functional gland and TH secretion is very low (Leloup \& Buscaglia 1977, Regard 1978). The onset of prometamorphosis (stage 54 in X. laevis) is characterized by an increase in circulating TH plasma levels and peak levels of $\mathrm{TH}$ in blood plasma are present during mid climax (stages 60-62 in X. laevis). The distinct changes reported for blood plasma TH levels during X. laevis metamorphosis (Leloup \& Buscaglia 1977) are closely correlated to alterations in histological and biochemical markers of thyroid gland activity (Regard 1978). Given the central role of NIS for normal thyroid gland function, we devised a number of experiments to examine the expression of NIS mRNA in the thyroid gland of $X$. laevis tadpoles under different physiological conditions.

An initial qualitative RT-PCR analysis of NIS mRNA tissue distribution in stage 57/58 tadpoles revealed detectable levels in thyroid, stomach, and kidney tissue but failed to demonstrate expression in liver, heart, or lung tissue. These results corroborate the recent demonstration of NIS mRNA expression in stomach and kidney of $X$. laevis (Carr et al. 2003), whereas the detection of NIS in X. laevis thyroid tissue represents a novel finding. The physiological meaning of NIS expression in stomach and kidney of $X$. laevis is not yet clear. The tissue distribution of NIS mRNA observed in X. laevis tadpoles is in accordance with several mammalian studies reporting increased NIS expression in thyroid and gastric mucosa but very low or undetectable levels in liver, heart, and lung (Perron et al. 2001, Bruno et al. 2004). Inconsistent results have been obtained in mammalian studies of NIS expression in the kidney. Spitzweg et al. (2001) reported positive detection of NIS mRNA in human kidney by RT-PCR and ribonuclease protection assay, whereas other studies failed to detect NIS in kidney using various techniques (Perron et al. 2001, Bruno et al. 2004).

During spontaneous development, the level of NIS mRNA expression in thyroid glands of $X$. laevis tadpoles showed distinct changes. The observation of weak mRNA expression of NIS at premetamorphic stages is in accordance with earlier studies that reported low rates of thyroidal iodide uptake in the premetamorphic amphibian thyroid gland (Saxen et al. 1957, Regard 1978). Furthermore, the increase in NIS mRNA expression observed during prometamorphosis to peak expression levels at early climax stages followed by a distinct decline towards the end of metamorphosis correlates well with developmental profiles reported for thyroidal iodide uptake (Saxen et al. 1957, Regard 1978) and TH levels in X. laevis tadpoles (Leloup \& Buscaglia 1977, Krain \& Denver 2004). In addition, our own morphometric measurements of follicular cell height, considered as a histological marker of thyroid follicular cell activity (Kalisnik 1972), suggest a relationship between NIS mRNA expression and thyroid follicular cell activity during metamorphosis. Together, these data implicate that the increase in NIS mRNA expression coincides temporally with the onset of elevated iodide-trapping, TH synthesis, and secretion. Although the present study determined only the expression 
of NIS mRNA and not the functional protein, our data strongly suggest that the increases in thyroidal iodide uptake during metamorphic development, as observed in previous studies (Saxen et al. 1957, Regard 1978), are mediated at least in part by increased transcription of the NIS gene.

TSH is the primary hormonal regulator of thyroid gland function and mammalian studies have shown that most effects of TSH are mediated by modulation of thyroid-specific gene expression (Vassart \& Dumont 1992, Yamazaki et al. 2003). In previous studies with amphibian tadpoles, mammalian TSH preparations have been shown to stimulate thyroidal iodide uptake (Lynn \& Dent 1961, Hourdry \& Regard 1975) but the effects of TSH on NIS gene expression have not been examined in any amphibian species so far. We first wished to characterize the role of TSH in the developmental regulation of NIS mRNA expression during metamorphosis. Since an anti-TSH antibody to examine TSH plasma concentrations in tadpoles is not yet available for X. laevis, we determined TSH $\beta$ mRNA expression in pituitary tissue of the same tadpoles that were sampled for thyroid gland gene expression analysis. Comparison of pituitary TSH $\beta$ mRNA and thyroidal NIS mRNA expression patterns revealed a close correlation between the developmental profiles of both genes. Notably, the first induction of increased thyroidal NIS mRNA and pituitary TSH $\beta$ mRNA expression occurred at the same developmental stage (stage 54 in this study), peak expression of pituitary TSH $\beta$ mRNA (stage 58) shortly precedes the maximum expression of thyroidal NIS mRNA (stage 60), and the expression of both genes is down-regulated towards the end of the metamorphosis. Although the precise relationship between pituitary TSH $\beta$ mRNA expression and circulating TSH concentrations remains to be elucidated in $X$. laevis tadpoles, these data suggest a role of increased TSH synthesis and secretion in the up-regulation of NIS mRNA expression during metamorphic development.

Further support for this hypothesis was obtained from in vivo experiments involving 12-day treatment of $X$. laevis tadpoles with known anti-thyroidal compounds to induce hypothyroidism and goiter development. With sodium perchlorate and ETU, we selected two goitrogenic compounds that inhibit thyroid gland function via different modes of action; the perchlorate anion inhibits thyroidal iodide uptake, whereas ETU inhibits organification of iodide (Doerge \& Takazawa 1990, Wolff 1998). The test concentrations chosen for these compounds are known to severely suppress $\mathrm{TH}$-dependent development, while inducing thyroid gland hyperplasia in X. laevis tadpoles (Tietge et al. 2005, Opitz et al. 2006a). In the present study, treatment of tadpoles for 12 days with sodium perchlorate and ETU induced a significantly increased expression of TSH $\beta$ mRNA in the pituitary. Further histological examination of thyroid gland sections from perchlorate- and ETU-treated tadpoles provided evidence for glandular enlargement, follicular cell hypertrophy, and hyperplasia, most likely resulting from stimulation of thyroid follicular cells by elevated TSH plasma levels. It should be noted, however, that thyroid gland histology also revealed marked differences in the follicular architecture induced by these two compounds. Irrespective of the different modes of perchlorate and ETU action on thyroid gland function, both treatments led to a marked increase in thyroidal NIS mRNA expression. Results from this experiment are, thus, in accordance with data from recent mammalian studies showing that experimental induction of goiter is associated with increased pituitary TSH expression and concomitant up-regulation of thyroidal NIS expression (Levy et al. 1997, Uyttersprot et al. 1997). Moreover, results from this study suggest that goitrogen-induced overexpression of TSH in X. laevis tadpoles provides a meaningful model to study TSHdependent gene expression in amphibian thyroid glands in an in vivo context. In turn, the results of the present study suggest that analysis of gene expression in the thyroid gland may provide a meaningful endpoint measurement in amphibian bioassays for detection of xenobiotics with thyroid systemdisrupting activities (Kloas 2002, Opitz et al. 2006a, 2006b).

Using ex vivo thyroid gland culture experiments, we could demonstrate a marked up-regulation of NIS mRNA by bTSH. The effect of bTSH on NIS gene expression was rapid as NIS mRNA induction was observed already after $6 \mathrm{~h}$ of bTSH treatment. Moreover, in the presence of bTSH, elevated expression of NIS mRNA was maintained for up to $48 \mathrm{~h}$ in cultured thyroid glands. Similar temporal induction characteristics, i.e., rapid and persistent induction of NIS mRNA by TSH treatment, have recently been reported in different rat thyroid follicular cell lines (Kogai et al. 1997, Trapasso et al. 1999). In contrast, NIS induction by TSH was delayed in primary porcine thyrocytes, suggesting the existence of species-specific differences in time-courses of NIS up-regulation (Selmi-Ruby et al. 2003). The up-regulation of NIS mRNA by bTSH could be fully reproduced if thyroid glands were co-cultured with freshly dissected pituitary glands, demonstrating that pituitaries from $X$. laevis tadpoles secrete a bTSH-mimicking factor, which is most likely endogenous TSH. However, at present, we cannot exclude the possibility that other pituitary hormones such as gonadotropins and prolactin contribute also to the regulation of thyroid-specific gene expression (Regard 1978, Sakai et al. 1991). Another remarkable characteristic of the ex vivo thyroid gland culture model was the rapid disappearance of detectable NIS mRNA in thyroid glands cultured in TSHfree culture medium. A similar disappearance of NIS mRNA has previously been reported for FRTL-5 cells (Kogai et al. 1997) and primary porcine thyrocytes cultured in TSH-free medium (Selmi-Ruby et al. 2003). The expression of thyroid peroxidase and thyroglobulin mRNA was much less drastically reduced during incubation of $X$. laevis thyroid glands in TSH-deprived medium (unpublished observations). These observations suggest that the maintenance of NIS mRNA might be more strictly dependent on the presence of TSH compared to other thyroid-specific genes, an interpretation that is also supported by recent studies on mammalian NIS expression (Marians et al. 2002). Experiments using realtime quantitative RT-PCR, as applied in other studies 
(Wagner et al. 2002), are currently in progress to further examine the kinetics of NIS mRNA down-regulation after TSH withdrawal from culture medium.

In mammalian thyroid follicular cells, cAMP-dependent activation of PKA has been shown to be the most important signaling pathway of TSH to induce changes in gene expression (Vassart \& Dumont 1992, Kimura et al. 2001). The demonstration that the adenylate cyclase agonist forskolin and the cAMP analog db-cAMP mimic the stimulatory effects of bTSH on NIS mRNA expression in $X$. laevis thyroid glands suggests that the cAMP-dependent control of NIS gene transcription is conserved in amphibian thyrocytes. Given the known stimulatory action of db-cAMP and forskolin on PKA activity in X. laevis tissues (Liou et al. 2001), our data on NIS mRNA expression indicate similar regulatory mechanisms in the amphibian thyroid gland compared to what has been reported in a large number of mammalian studies. However, further studies examining TSH-dependent changes in cellular cAMP content (Bidey et al. 1981) and the effects of specific inhibitors of PKA activity on NIS expression (Taki et al. 2002) will be required to confirm PKA activation and to delineate TSH-induced signaling cascades, leading to increased NIS mRNA expression in $X$. laevis thyrocytes. Another issue that needs to be addressed is NIS protein expression and targeting of NIS to the plasma membrane in amphibian thyroid cells.

Three thyroid-specific transcription factors, Pax8, Nkx2 1 , and FoxE1, have been shown to mediate the TSH/cAMP effects on gene transcription in mammalian thyroid follicular cells (Damante et al. 2001), but very little is known about the role of thyroid-specific transcription factors in nonmammalian vertebrates (Wendl et al. 2002, Elsalini et al. 2003). Using the whole mount in situ hybridization, Nkx2 1 mRNA expression has been observed in the thyroid primordium of $X$. laevis embryos (Hollemann \& Pieler 2000, Small et al. 2000), but expression of $\mathrm{Nkx} 2 \cdot 1 \mathrm{mRNA}$ in thyroid glands of metamorphosing tadpoles has not been resolved. Moreover, Heller \& Brändli (1999) noted that they failed to detect Pax8 mRNA expression in the region of the thyroid anlage of $X$. laevis embryos by whole mount in situ hybridization. Using semiquantitative RT-PCR, we successfully detected both $\mathrm{Nkx} 2 \cdot 1$ and Pax8 mRNA expression in the thyroid gland of X. laevis tadpoles from premetamorphic stage 51 throughout metamorphosis. It should be noted that our observation of Pax8 mRNA expression in the thyroid gland is not necessarily contradictory to the results of Heller \& Brändli (1999), since the developmental stages examined in the two studies do not overlap. Moreover, results from our qualitative RT-PCR analysis of $\operatorname{Pax} 8$ and $\mathrm{Nkx} 2 \cdot 1$ tissue distribution are in accordance with previous reports on restricted extrathyroidal expression domains for Pax8 (kidney) and Nkx2.1 (lung) in mammals (Damante et al. 2001) and X. laevis (Heller \& Brändli 1999, Hollemann \& Pieler 2000, Small et al. 2000).

Pax8 and Nkx2 1 mRNA expression increased rapidly during prometamorphosis and elevated expression levels were maintained throughout metamorphosis. The temporal coincidence of elevated Pax8 and Nkx2 1 mRNA expression and increased thyroid gland activity during prometamorphosis and climax stages suggests a role for these transcription factors in the regulation of thyroid gland function as previously shown for mammalian species. The factors that stimulate the onset of increased expression of Pax8 and $\mathrm{Nkx} 2 \cdot 1 \mathrm{mRNA}$ in the thyroid gland during the transition from pre- to prometamorphic stages are currently unknown. A primary candidate for the regulation of Pax8 mRNA expression might be TSH. In mammalian thyroid cell cultures, TSH has been shown to up-regulate Pax8 mRNA and protein expression in a cAMP-dependent manner (Fabbro et al. 1998, Mascia et al. 2002). Results from our X. laevis thyroid gland culture experiments are in line with these observations, since moderate increases in Pax8 mRNA were consistently detected after TSH treatment. Notably, in vivo treatment of tadpoles with perchlorate or ETU failed to increase thyroid gland Pax8 expression over control levels. However, taking into account the different developmental stages of the sampled test animals and the developmental expression profile observed for Pax8 during spontaneous metamorphosis, it appears that the goitrogen-treated tadpoles displayed higher levels of Pax8 mRNA expression as one would expect for their early developmental stage.

The moderate up-regulation of Nkx2.1 mRNA by TSH in our organ culture experiments would similarly indicate a role for TSH in the positive control of $\mathrm{Nkx} 2 \cdot 1 \mathrm{mRNA}$ expression. Results from mammalian studies on TSH regulation of $\mathrm{Nkx} 2 \cdot 1$ expression are contradictory as either no effects (Fabbro et al. 1998) or a down-regulation of $\mathrm{Nkx} 2 \cdot 1$ expression by TSH has been reported (Saito et al. 1997b). The latter response has been suggested to contribute to a short intra-thyroidal feedback loop, fine tuning the responsiveness of thyroid follicular cells to TSH stimulation (Suzuki et al. 1999). For the FRTL-5 cell line, a recent study by Medina et al. (2000) demonstrated that TSH effects on $\mathrm{Nkx} 2 \cdot 1$ expression were dependent on the hormonal background of the media used for incubation, since downregulation of $\mathrm{Nkx} 2 \cdot 1$ by $\mathrm{TSH}$ required the presence of insulin in the medium. Further studies are needed to clarify the potential modulating effects of insulin supplementation on the response of $\mathrm{Nkx} 2 \cdot 1$ expression to TSH treatment in cultured thyroid glands of X. laevis tadpoles.

In conclusion, the present study provides the first characterization of the developmental profile and hormonal regulation of NIS, Pax8 and Nkx2.1 gene expression in the amphibian thyroid gland. The developmental NIS mRNA expression profile in the thyroid gland was closely related to previously reported profiles of other well-established markers of thyroid gland activity such as thyroidal iodide uptake, T4 secretion, and thyroid gland histology. This suggests that NIS mRNA expression could represent a valuable molecular marker of thyroid gland activity in metamorphosing X. laevis tadpoles. We also developed two experimental models, in vivo induction of goitrogenesis and ex vivo organ culture of whole thyroid glands, that allowed for the examination of 
TSH-dependent changes in thyroid gland gene expression in $X$. laevis. To this end, the results from the organ culture experiments led us to conclude that TSH, presumably acting via the cAMP-PKA pathway, is a potent stimulator of NIS mRNA expression in the amphibian thyroid gland. Based on the findings of the present study, it will be interesting to develop an antibody to $X$. laevis NIS in order to study the regulation of NIS expression at the protein level.

\section{Acknowledgements}

This study was supported by the German Federal Environmental Agency under contract no. 20467 454. The authors thank G Adam and M Simon for help with performing the histological analyses and Prof. J Köhrle for critical comments on an earlier draft of the manuscript. The authors declare that there is no conflict of interest that would prejudice the impartiality of this scientific work.

\section{References}

Alexander WD \& Wolff J 1966 Thyroidal iodide transport: relation between transport, goitrogenic and antigoitrogenic properties of certain anions. Endocrinology 78 581-590.

Altmann A, Schulz RB, Glensch G, Eskerski H, Zitzmann S, Eisenhut M \& Haberkorn U 2005 Effects of Pax8 and TTF-1 thyroid transcription factor gene transfer in hepatoma cells: imaging of functional protein-protein interaction and iodide uptake. Journal of Nuclear Medicine 46 831-839.

Bidey SP, Marshall NJ \& Ekins RP 1981 Characterisation of the cyclic AMP response to thyrotrophin in monolayer cultures of normal human thyroid cells. Acta Endocrinologica 98 370-376.

Bruno R, Giannasio P, Ronga G, Baudin E, Travagli JP, Russo D, Filetti S \& Schlumberger M 2004 Sodium iodide symporter expression and radioiodine distribution in extrathyroidal tissues. Journal of Endocrinological Investigation 27 1010-1014.

Carr DL, Laharrague F, Kahn B, Pressley TA \& Carr JA 2003 Molecular characterization of a putative sodium/iodide symporter in the South African clawed frog, Xenopus laevis (abstract). Annals of the New York Acadamy of Sciences 986 711-712.

Dai G, Levy O \& Carrasco N 1996 Cloning and characterization of the thyroid iodide transporter. Nature 379 458-460.

Damante G, Tell G \& Di Lauro R 2001 A unique combination of transcription factors controls differentiation of thyroid cells. Progress in Nucleic Acid Research and Molecular Biology 66 307-356.

De La Vieja A, Dohan O, Levy O \& Carrasco N 2000 Molecular analysis of the sodium/iodide symporter: impact on thyroid and extrathyroid pathophysiology. Physiological Reviews 80 1083-1105.

Denver RJ 1988 Several hypothalamic peptides stimulate in vitro thyrotropin secretion by pituitaries of anuran amphibians. General and Comparative Endocrinology 72 383-393.

Doerge DR \& Takazawa RS 1990 Mechanism of thyroid peroxidase inhibition by ethylenethiourea. Chemical Research in Toxicology 3 98-101.

Dohan O, De la Vieja A, Paroder V, Riedel C, Artani M, Reed M, Ginter CS \& Carrasco N 2003 The sodium/iodide symporter (NIS): characterization, regulation, and medical significance. Endocrine Reviews 24 48-77.

Elsalini OA, von Gartzen J, Cramer M \& Rohr KB 2003 Zebrafish hhex, $n k 2.1 a$, and pax2.1 regulate thyroid growth and differentiation downstream of Nodal-dependent transcription factors. Developmental Biology 263 67-80.

Endo T, Kaneshige M, Nakazato M, Ohmori M, Harii N \& Onaya T 1997 Thyroid transcription factor- 1 activates the promoter activity of rat thyroid $\mathrm{Na}^{+} / \mathrm{I}^{-}$symporter gene. Molecular Endocrinology 11 1747-1755.
Fabbro D, Pellizzari L, Mercuri F, Tell G \& Damante G 1998 Pax-8 protein levels regulate thyroglobulin gene expression. Journal of Molecular Endocrinology 21 347-354.

Goleman WL, Carr JA \& Anderson TA 2002 Environmentally relevant concentrations of ammonium perchlorate inhibit thyroid function and alter sex ratios in developing Xenopus laevis. Environmental Toxicology and Chemistry 21 590-597.

Heller N \& Brändli AW 1999 Xenopus Pax-2/5/8 orthologues: novel insights into Pax gene evolution and identification of Pax- 8 as the earliest marker for otic and pronephric cell lineages. Developmental Genetics 24 208-219.

Hollemann T \& Pieler T 2000 Xnkx-2.1: a homeobox gene expressed during early forebrain, lung and thyroid development in Xenopus laevis. Development Genes and Evolution 210 579-581.

Hourdry J \& Regard E 1975 Quantitative measurement of colloidal iodine in thyroid follicles of Xenopus larva by x-ray spectrometry: effects of hypophysectomy and the administration of TSH. General and Comparative Endocrinology 27 277-288.

Kalisnik M 1972 A histometric thyroid gland activation index. Journal of Microscopy 95 345-348.

Kimura T, Van Keymeulen A, Golstein J, Fusco A, Dumont JE \& Roger PP 2001 Regulation of thyroid cell proliferation by TSH and other factors: a critical evaluation of in vitro models. Endocrine Revievs 22 631-656.

Klein SL, Strausberg RL, Wagner L, Pontius J, Clifton SW \& Richardson P 2002 Genetic and genomic tools for Xenopus research: the NIH Xenopus initiative. Developmental Dynamics 225 384-391.

Kloas W 2002 Amphibians as model for the study of endocrine disruptors. International Review of Cytology 216 1-57.

Kogai T, Endo T, Saito T, Miyazaki A, Kawaguchi A \& Onaya T 1997 Regulation by thyroid-stimulating hormone of sodium/iodide symporter gene expression and protein levels in FRTL-5 cells. Endocrinology 138 2227-2232.

Krain LP \& Denver RJ 2004 Developmental expression and hormonal regulation of glucocorticoid and thyroid hormone receptors during metamorphosis in Xenopus laevis. Journal of Endocrinology 181 91-104.

Leloup J \& Buscaglia M 1977 La triiodothyronine, hormone de la metamorphose des amphibiens. Comptes Rendus de l'Academie des Sciences 284 2261-2263.

Levy O, Dai G, Riedel C, Ginter CS, Paul EM, Lebowitz AN \& Carrasco N 1997 Characterization of the thyroid $\mathrm{Na}^{+} / \mathrm{I}^{-}$symporter with an antiCOOH terminus antibody. PNAS 94 5568-5573.

Liou HH, Lin W, Liou HC, Huang TF \& Fu WM 2001 Modulation of protein kinase A activation by fibronectin matrix proteins at developing neuromuscular synapses in Xenopus laevis cell cultures. Molecular Pharmacology 60 348-354.

Lynn WG \& Dent JN 1960 The action of various goitrogens in inhibiting localization of radioiodine in the thyroid and thymus glands of larval tree frogs. Biological Bulletin 118 430-438.

Lynn WG \& Dent JN 1961 A comparison of the responses of Triturus and Desmognathus to TSH administration. Biological Bulletin 120 54-61.

Marians RC, Ng L, Blair HC, Unger P, Graves PN \& Davies TF 2002 Defining thyrotropin-dependent and -independent steps of thyroid hormone synthesis by using thyrotropin receptor-null mice. PNAS 99 15776-15781.

Mascia A, Nitsch L, Di Lauro R \& Zannini M 2002 Hormonal control of the transcription factor Pax8 and its role in the regulation of thyroglobulin gene expression in thyroid cells. Journal of Endocrinology 172 163-176.

Medina DL, Suzuki K, Pietrarelli M, Okajima F, Kohn LD \& Santisteban P 2000 Role of insulin and serum on thyrotropin regulation of thyroid transcription factor- 1 and pax-8 genes expression in FRTL-5 thyroid cells. Thyroid 10 295-303.

Nieuwkoop PD \& Faber J 1994 Normal Table of Xenopus laevis (Daudin). New York, NY, USA: Garland.

Norris DO \& Platt JE 1973 Effects of pituitary hormones, melatonin, and thyroidal inhibitors on radioiodide uptake by the thyroid glands of larval and adult tiger salamanders, Ambystoma tigrinum (Amphibia: Caudata). General and Comparative Endocrinology 21 368-376.

Ohno M, Zannini M, Levy O, Carrasco N \& di Lauro R 1999 The paireddomain transcription factor Pax8 binds to the upstream enhancer of the rat 
sodium/iodide symporter gene and participates in both thyroid-specific and cyclic-AMP-dependent transcription. Molecular and Cellular Biology 19 2051-2060.

Opitz R, Braunbeck T, Bögi C, Pickford DB, Nentwig G, Oehlmann J, Tooi O, Lutz I \& Kloas W 2005 Description and initial evaluation of a Xenopus metamorphosis assay for detection of thyroid system-disrupting activities of environmental compounds. Environmental Toxicology and Chemistry 24 653-664.

Opitz R, Hartmann S, Blank T, Braunbeck T, Lutz I \& Kloas W $2006 a$ Evaluation of histological and molecular endpoints for enhanced detection of thyroid system disruption in Xenopus laevis tadpoles. Toxicological Sciences $90337-348$

Opitz R, Lutz I, Nguyen NG, Scanlan TS \& Kloas W $2006 b$ Analysis of thyroid hormone receptor $\beta$ A mRNA expression in Xenopus laevis tadpoles as a means to detect agonism and antagonism of thyroid hormone action. Toxicology and Applied Pharmacology 212 1-13.

Paire A, Bernier-Valentin F, Rabilloud R, Watrin C, Selmi-Ruby S \& Rousset B 1998 Expression of $\boldsymbol{\alpha}$ - and $\beta$-subunits and activity of $\mathrm{Na}^{+} \mathrm{K}^{+}$ ATPase in pig thyroid cells in primary culture: modulation by thyrotropin and thyroid hormones. Molecular and Cellullar Endocrinology 146 93-101.

Perron B, Rodriguez AM, Leblanc G \& Pourcher T 2001 Cloning of the mouse sodium iodide symporter and its expression in the mammary gland and other tissues. Journal of Endocrinology 170 185-196.

Pohlenz J \& Refetoff S 1999 Mutations in the sodium/iodide symporter (NIS) gene as a cause for iodide transport defects and congenital hypothyroidism. Biochimie 81 469-476.

Regard E 1978 Cytophysiology of the amphibian thyroid gland through larval development and metamorphosis. International Review of Cytology $\mathbf{5 2}$ $81-118$.

Saito T, Endo T, Kawaguchi A, Ikeda M, Nakazato M, Kogai T \& Onaya T $1997 a$ Increased expression of the $\mathrm{Na}^{+} / \mathrm{I}^{-}$symporter in cultured human thyroid cells exposed to thyrotropin and in Graves' thyroid tissue. Journal of Clinical Endocrinology and Metabolism 82 3331-3336.

Saito T, Endo T, Nakazato M, Kogai T \& Onaya T $1997 b$ Thyroid-stimulating hormone-induced down-regulation of thyroid transcription factor 1 in rat thyroid FRTL-5 cells. Endocrinology 138 602-606.

Sakai M, Hanaoka Y, Tanaka S, Hayashi H \& Kikuyama S 1991 Thyrotropic activity of various adenohypophyseal hormones of the bullfrog. Zoological Science 8 929-934.

Saxen L, Saxen E, Toivonen S \& Salimaki K 1957 Quantitative investigation on the anterior pituitary-thyroid mechanism during frog metamorphosis. Endocrinology 61 35-44.

Selmi-Ruby S, Watrin C, Trouttet-Masson S, Bernier-Valentin F, Flachon V, Munari-Silem Y \& Rousset B 2003 The porcine sodium/iodide symporter gene exhibits an uncommon expression pattern related to the use of alternative splice sites not present in the human or murine species. Endocrinology 144 1074-1085.

Shi YB 1999 Amphibian Metamorphosis. From Morphology to Molecular Biology. New York, NY, USA: Wiley-Liss.

Small EM, Vokes SA, Garriock RJ, Li D \& Krieg PA 2000 Developmental expression of the Xenopus Nkx2-1 and Nkx2-4 genes. Mechanisms of Development 96 259-262.

Spitzweg C, Dutton CM, Castro MR, Bergert ER, Goellner JR, Heufelder AE \& Morris JC 2001 Expression of the sodium iodide symporter in human kidney. Kidney International 59 1013-1023.

Suzuki K, Mori A, Lavaroni S, Miyagi E, Ulianich L, Katoh R, Kawaoi A \& Kohn LD 1999 In vivo expression of thyroid transcription factor-1 RNA and its relation to thyroid function and follicular heterogeneity: identification of follicular thyroglobulin as a feedback suppressor for thyroid transcription factor-1 RNA levels and thyroglobulin synthesis. Thyroid 9 319-331.

Taki K, Kogai T, Kanamoto Y, Hershman JM \& Brent GA 2002 A thyroidspecific far-upstream enhancer in the human sodium/iodide symporter gene requires Pax- 8 binding and cyclic adenosine $3^{\prime}, 5^{\prime}$-monophosphate response element-like sequence binding proteins for full activity and is differentially regulated in normal and thyroid cancer cells. Molecular Endocrinology 16 2266-2282.

Tietge JE, Holcombe GW, Flynn KM, Kosian PA, Korte JJ, Anderson LE, Wolf DC \& Degitz SJ 2005 Metamorphic inhibition of Xenopus laevis by sodium perchlorate: effects on development and thyroid histology. Environmental Toxicology and Chemistry 24 926-933.

Tonacchera M, Pinchera A, Dimida A, Ferrarini E, Agretti P, Vitti P, Santini F, Crump K \& Gibbs J 2004 Relative potencies and additivity of perchlorate, thiocyanate, nitrate, and iodide on the inhibition of radioactive iodide uptake by the human sodium iodide symporter. Thyroid 14 1012-1019.

Trapasso F, Iuliano R, Chiefari E, Arturi F, Stella A, Filetti S, Fusco A \& Russo D 1999 Iodide symporter gene expression in normal and transformed rat thyroid cells. European Journal of Endocrinology 140 $447-451$.

Uyttersprot N, Pelgrims N, Carrasco N, Gervy C, Maenhaut C, Dumont JE $\&$ Miot F 1997 Moderate doses of iodide in vivo inhibit cell proliferation and the expression of thyroperoxidase and $\mathrm{Na}^{+} / \mathrm{I}^{-}$symporter mRNAs in $\operatorname{dog}$ thyroid. Molecular and Cellular Endocrinology 131 195-203.

Vassart G \& Dumont JE 1992 The thyrotropin receptor and the regulation of thyrocyte function and growth. Endocrine Reviews 13 596-611.

Viglietto G, Romano A, Manzo G, Chiappetta G, Paoletti I, Califano D, Galati MG, Mauriello V, Bruni P, Lago CT et al. 1997 Upregulation of the angiogenic factors PlGF, VEGF and their receptors (Flt-1, Flk-1/KDR) by TSH in cultured thyrocytes and in the thyroid gland of thiouracil-fed rats suggest a TSH-dependent paracrine mechanism for goiter hypervascularization. Oncogene 15 2687-2698.

Wagner S, Aust G, Schott M, Scherbaum WA, Feldkamp J \& Seissler J 2002 Regulation of sodium-iodide-symporter gene expression in human thyrocytes measured by real-time polymerase chain reaction. Experimental and Clinical Endocrinology and Diabetes 110 398-402.

Wendl T, Lun K, Mione M, Favor J, Brand M, Wilson SW \& Rohr KB 2002 pax2.1 is required for the development of thyroid follicles in zebrafish. Development 129 3751-3760.

Wolff J 1998 Perchlorate and the thyroid gland. Pharmacological Reviews $\mathbf{5 0} 89-105$.

Wright ML, Blanchard LS, Pikula A \& Labieniec KE 1995 Circadian rhythms of thyroid secretion, morphometry, and cell division in prometamorphic and climax Rana tadpoles. General and Comparative Endocrinology 99 75-84.

Yamazaki K, Yamada E, Kanaji Y, Yanagisawa T, Kato Y, Takano K, Obara T \& Sato K 2003 Genes regulated by thyrotropin and iodide in cultured human thyroid follicles: analysis by cDNA microarray. Thyroid 13 149-158. Yen PM 2001 Physiological and molecular basis of thyroid hormone action. Physiological Reviews 81 1097-1142.

Received in final form 27 March 2006
Accepted 29 March 2006
Made available online as an Accepted Preprint
25 April 2006

Received in final form 27 March 2006

Made available online as an Accepted Preprint 25 April 2006 